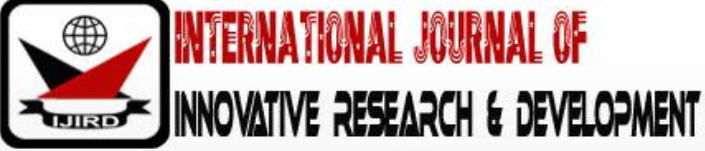

ISSN 2278 - 0211 (Online)

\section{Information and Communication Technology Infrastructures and Tertiary Institution Governance in Kogi State, Nigeria: An Assessment}

\author{
Dr. Hassan Achimugu \\ Lecturer, Department of Public Administration, \\ Kogi State University, Anyigba, Nigeria \\ Oguche Blessing Abraham \\ Administrative Officer, Department of Registry/ Establishement \\ Kogi State University, Anyigba, Nigeria
}

\begin{abstract}
:
Information and Communication technology is significantly changing almost every sphere of human endeavor, and can conveniently be said to be the culture of the $21^{\text {st }}$ century. The changes it has brought, with regards to ease and speed of doing hitherto cumbersome and time consuming tasks is one of the reasons why segments and various professional divides seem in a haste to reform their rules of engagements leveraging on the potentials of ICTs. Tertiary educational institutions in Kogi State have made a handful of attempts at mainstreaming ICTs in delivering their mandate. This paper therefore assesses the Effectiveness of Information and Communications Technology infrastructures in the Kogi State University Anyigba, the Federal Polytechnic Idah, and Kogi State College of Education, Ankpa. The study adopts a Cross-sectional survey research design, guided by the technophile Model, and a target population of 2,360, from which a sample size of 346 respondents was drawn Using the Krejcie and Morgan sampling table. Data was collection through the use of self-administered questionnaire and interviews. Analyses was completed using simple percentages and frequency tables. The findings attest to obsolete and inadequate ICT facilities in the institutions under investigation. Particularly, internet connectivity (wifi), power supply to aid effective utilization of ICTs in these institutions, internet radios in Schools/ Faculties, Departments and Units in institutions under studies are poor, and in most cases dilapidated and out of use. Besides, functional staff e-mail services for effective communication in these institutions were either not provided for, or not functional. It was equally found that most members of staff lack the requisite knowledge for the application of ICT in the discharge of official responsibilities, among others. The study recommends that all staff and students of the institutions should be given ICT trainings to aid their performance in this dynamic and technology oriented 21 ${ }^{\text {st }}$ century. Obsolete ICT infrastructures should be replaced with new and modern ones. There should be steady and uninterrupted power supply. Tertiary institutions should make the institution accessible to the internet so that, all staff and student should access the internet in their closet even if it will attract more funds. Mild user charges may be compulsorily levied. Such charges could be made a component of the tuition fee of students and drawn on the salaries of members of staff, from source. This would also insulate the institution from directly incurring more running cost, while at the same time ensuring efficiency.
\end{abstract}

Keywords: Information and communication technology, infrastructure, tertiary institutions

\section{Introduction}

Information and Communication Technology (ICT) can be described as a new entrant in Nigeria, if one considers when the country adopted a policy on ICT. The country got a National Policy for Information Technology in March 2001, establishing the Nigerian National Information Technology Development Agency (NITDA) in April 2001 but got an enabling law giving legal recognition to the Agency in April 2007 (Iboma, 2007; Okonji, 2007). This state of affairs explains the novelty of ICT in Nigeria. Interestingly, the National Policy for Information Technology is explicit on using ICT as the bedrock for national survival and development. In its mission statement the policy adopted to use ICT for "education" in its quest to contribute to the developmental strives of the country. The policy even proposed to make the use of IT mandatory at all levels of educational institutions through adequate financial provision for tools and resources (National Policy for Information Technology,2007). With such national stance, a research into the implantation of this concept in tertiary Institutions can be justified.

The use of ICT could be an effective tool in attaining any goal set by Tertiary Institutions, the Society and the Government. Many investigations and researches have revealed that ICT is an important fulcrum on which modern society revolves around. This mean it is an effective instrument in bringing change which could lead to faster advancement in every sector of human life, most especially if effectively and efficiently managed. Historically, when modern technology 
emerges first in other parts of the world including Africa and precisely Nigeria, traditional systems of instruction was common before the recent replacement with a new one that is ICT-based, some of the changes introduced were partly adopted while some were wholly adopted in schools, most especially in the developing countries, Nigeria inclusive. These adoptions or uses were visible in almost all levels of education system- pre-primary, primary, secondary, and Tertiary Institutions (Umar 2015).

\section{Conceptual Framework}

\subsection{Information and Communication Technology (ICT)}

ICT means Information and Communication Technology. It is a broad concept that combines telecommunications, computing and broadcasting devices. It covers any product that will store, retrieve, manipulate, transmit or receive information electronically. These include communication devices and applications like television, radio, computer, cellular phones, satellite systems, network hardware and software, and the various services and applications associated with these, including video conferencing.

However, like most such broad concepts, there has not been a generally accepted definition for ICT. This implies that there are varieties of definitions of this concept. But the Organization for Economic Cooperation and Development (OECD, 2004) stipulates benchmarks for a product to be considered as ICT. According to OECD, for a product of a manufacturing or a service industry to be considered as ICT, it must meet the following criteria: it should be intended to fulfil the function of information processing and communication including transmission and display; it should use electronic processing to detect, measure and/ or record physical phenomena or to control a physical process; the components primarily intended for use in such products should also be included; it should enable the function of information processing and communication by electronic means; the service provided must go beyond simply the supply of goods(OECD, 2004).

Moreover, in the words of Akir (2006), ICT is a term that refers to standalone computers, networked devices and telecommunication technologies with multimodal interface, mobile phones/devices with capability to perform data communication, and other technologies that allow multimodal and interactive communication. The National Policy for Information Technology (2007) sees ICT as computers, ancillary equipment, software and firmware (Hardware) and similar procedures, services (including support services) and related resources. This, according to the policy, "includes any equipment or interconnected system or subsystem of equipment that is used in the automatic acquisition, storage, manipulation, management, movement, control, display, switching, interchange, transmission or reception of data or information. In the same vein, citing computers, the internet, broadcasting technologies (radio and television), and telephony as examples, Tinio (2002) defines ICT as diverse set of technological tools and resources used to communicate, and to create, disseminate, store, and manage information.

It has been mentioned that ICT is a broad field. The definitions above are obvious attempts to incorporate this wide-ranging concept into one definition. This leaves the definitions with keywords that depict the different aspects of ICT. The different aspects of ICT can be discerned from its definitions as the definitions are obvious attempts to incorporate the wide-ranging nature of the concept into one designation. Aspects of ICT therefore transverse devices used in telecommunications, computing and broadcasting sectors. These include devices and applications like television, radio, computer, cellular phones, satellite systems, network hardware and software, and the various services and applications associated with these, including video conferencing (Tinio, 2002). Furthermore, Nkanu (2006) identified computers, photocopiers, CD-ROM Databases, printers, videotapes, and audio tapes as some examples of ICT. It is obvious that these examples are themselves umbrellas covering other subordinate units, thus requiring further breaking down.

\subsection{History of Information Communication Technology (ICT)}

The origin of ICT usage can be traced back to the technological rivalry between Union of Soviet Socialist Republic (USSR) and United States of America (USA) in the mid-twentieth century. In 1957, the Soviet Union launched a space craft called "Sputnik". The success recorded in this venture was humiliating to the US, which was supposed to be leading the world in space programme. This challenge spurred the US to devote much time and funds into space research. This led to the formation of Advanced Research Project Agency (ARPA), which comprised military scientists and organizations in the private sector of the US economy. This synergy gave birth to mainframe computers, which were used and linked in a network for medium usage by all the researchers involved in the project. The network link, which was initially called ARPAnet, later metamorphosed into the Internet. Although the military later removed the space research aspect out of ARPA net and into a new body called National Aeronautics and Space Administration (NASA), ARPA net continued as Internet through private initiative and efforts to become an important global network for communication (Mohammed, 2007; Onyeneke, 2007; Achonna \& Yaya, 2008). The Internet has made it possible for people all over the world to communicate with one another effectively and inexpensively, hence its adoption in all spheres of human endeavour. As Aliyu (2007) rightly observes "Advances in ICT have facilitated the advancement of all professions".

\subsection{The Contributions of Information Communication Technology (ICT) to Socio-Economic Development}

Studies have shown that the rate of IT diffusion is correlated to the general level of socioeconomic development (Hargittai, 1999). A most recent finding is that ICT plays a vital role in advancing economic growth and reducing poverty. A survey of firms carried out in 56 developing countries finds that firms that use ICT grow faster, invest more, and are more productive and profitable than those that do not (Tahir 2012). 
ICTs can be used to directly influence the productivity, cost effectiveness and competitiveness in industries, which is the advantage developing countries can build their economies upon. Catching up on developed economies in terms of application of technology and resulting economic benefits had never been that easier. On the other hand, the results for not being able to adopt ICTs can also be disastrous (Tahir 2012).

Information and Communication Technology (ICT) network is the basic facility through which information needs of industry, commerce and agriculture can be satisfied. Industrial development requires the coordination of a series of operation, including the acquisition of supplies, recruitment of labour, control stocks, processing of materials, delivery of goods to buyers, as well as billing and record keeping. Information technology is vital to the effective development and control of many of these operations. Commerce is essentially on information processing activity, effective buying, selling and brokerage rely on the continual supply of up-to-date information regarding the availability of prices of goods and services. Farmers on the other hand, must not only grow food but they must sell effectively and buy seeds and fertilizer. They also need information on weather conditions, disease outbreaks and new agricultural techniques (Sylvester, 2011)

The social benefit of ICT is completely invaluable and cannot easily be listed. Notwithstanding, a good number of the social benefits can still be discussed. And these benefits include social interactions. Keeping in touch with friends and relations is one of the major social benefits of ICT. Igyor (1996) also declared the same view that ICT has changed the way transactions are conducted, the way in which information is circulated and the way in which we educate and inform ourselves.

\subsection{Information Communication Technology in Tertiary Institutions}

It is very clear that the possibilities and reach of information technologies can tear down territorial boundaries and make available equal information and knowledge of different categories as soon as necessary data are fed on the website. Consequently, the field of educational research, students and other educational providers are able to exchange knowledge, research findings and opportunities through publications and other outlets available in countries around the world (Jegede, 2002).

In higher education institutions, common ICT infrastructure and services are usually computers, the internet, and services related to the internet. Computer networks interconnect computers in the University for Easy Communication, sharing of resources, and collaboration among students and lectures. E-learning makes education available even to remote positions and teleconferencing/videoconferencing enables transfer of services of experts from other universities. Additionally, the internet makes information search and access to variety of information easy. All these mean that in higher education institutions, common ICT infrastructure and services are usually computers, the internet, and services related to the internet and they have obviously important impact on the activities conducted. Additionally, the extents to which an institution can provide all the necessary ICT facilities are a measure of the status of the institution.

\subsection{Implementation of ICTs in Tertiary Institutions of Learning in Nigeria}

The introduction of ICT into universities clearly changed the way education is conducted. It paves the way for a new pedagogical approach, where students are expected to play more active role than before (i.e. getting more involved in the learning process, being active participants of knowledge creation not mere recipients of knowledge). Using information and known ICT tools in education, students should be able to communicate, create preservatives in PowerPoint, and interact with colleagues and teachers using technology (Ekeke \& Mbachu, 2015).

Oduma (2013) likened ICT to a utility like water and electricity which plays a major role in education and has impacted on the quality and quantity of teaching and learning as well as research in educational methodology to initiate a new age in education. Internet as a digital tool of ICT has strengthen teaching and learning as it provides powerful resources and services for students, thereby enabling them meet their educational needs, it also allows for networking among students and teachers to facilitate exchange of ideas and improve opportunities for connecting schools to the world as learning is expanding beyond the classroom, so real life context can be established (Dotimi \& Hamilton-Ekeke, 2013). According to Nwezeh (2010), the information and communication technology revolution is sweeping through the world and the gale has even caught up with developing countries like Nigeria and Ghana. Information and communication technologies have introduced new methods of teaching and conducting research and have been brought into education facilities for online learning, teaching and research collaboration. While some university communities in some countries enjoy free or inexpensive Internet access, students and faculty/ staff in Nigeria must pay for time spent accessing the Internet, whether at a cyber café or in the library (although the library offers a discount). To improve ICT services in the library, therefore, researchers need to show how students and faculty/staff are using the Internet in the academic environment. University administration at many Nigerian universities see information and communication technologies as necessary in the process of learning and teaching. Information and communication technologies have given rise to new modes of organizing the educational environment in schools and new concepts in the teaching process as well as the remodelling of the roles played by the participants in the educational process.

\subsection{The Status of ICTs in Nigerian Tertiary Institutions}

The information and communication technology facilities in Nigeria institutions are those that assist in providing efficient and current information services for their use. In Nigeria, some of the resources that are harnessed for scholarly work include the use of various computer operating systems such as Microsoft Windows, software packages especially designed for library operations such as library software, software for indexing journals and newspapers, graphical library automation systems and data management applications. Internet technologies software include file protocol software, use 
net news groups, discussion groups, web directories, search engines, and e-mail services. These can harnessed by academics for good scholarly work.

Oduwole and Akpati (2003), sought to know the electronic resources provided by Nigerian libraries. When asked what electronic resources they provide, Nigerian university libraries identified online public access catalog, CD-ROM databases, electronic mail (e-mail) and internet browsing. The study found that students constitute the major category of users of electronic services in the university libraries surveyed. In a survey of cyber cafes which are facilities established in the university environment to aid learning and research in Delta State, Adomi, Omodeko and Otolo (2003) reported that $77.8 \%$ of the customers/ users of cafes were students. Ojedokun and Owolabi (2003) reported e-mails as the most used internet resource by staff and students.

\subsection{The Status of ICTs in Kogi East Tertiary Institutions}

\subsubsection{Kogi State University, Anyigba}

The idea to start a Directorate of ICT in Kogi State University is rooted in the long standing zeal and vision of a technologically forward and upward looking Vice Chancellor, Professor Hassan S. Isah who refers to this university as "an International State University making Anyigba town an international city". The Vice Chancellor of the university wants to bring the university to an international technologically compliant institution, one that offers her students and staff the environment to communicate and collaborate with the international or global community in terms of research, development and human capacity building in order to produce the best human resources and labour for the current global market kicked started the creation of Information Technology and Resource Centre (ITRC) to meet the university community ICT needs (KSU Annual Report, 2014/ 2015).

ITRC whose conception started with series of research findings, project development, think tank meetings and collaboration was finally and officially created on August 20, 2014.

\subsubsection{Kogi State College of Education, Ankpa}

In a personal communication with the Directorate Head of the ICT, Mr. Ocholi D.B., ICT Department in Kogi State College of Education, Ankpa was initiated by P.A. Enyaro in 1993. However, it started with Public Private Partnership (PPP) before the school took over as a computer department in 2011 under the leadership of Professor A.I. Ochepa and it was used for JAMB examination. The college later initiated computer department and was later changed to Digital centre which took over the activities of Information and Communication Technology (ICT). Then, in 2015 it became a Directorate under Professor Danladi Musa and the Directorate is being headed presently by Mr. Ocholi D.B.

\subsubsection{Federal Polytechnic, Idah}

According to the Head of ICT Unit, Federal Polytechnic Idah, Dr. James Oboro, ICT in Idah started in the year 2007 under the leadership of Professor Joseph Ndanusa Egila, the then Rector of the Polytechnic. The services of information and communication technology have been jointly provided by the Information and Communication Technology (ICT) and Management Information System (MIS) units of the Federal Polytechnic Idah. Their operations are purely computer oriented and they are principally charged with the responsibility of computer based services, support services for users and generally management and implementation of both the software and hardware devices for the smooth operation of the day-to-day activities of the Polytechnics.

Specifically, the scope of the operations include management of school's websites, web-design and administration, student admission data processing, course registration, departmental result processing, provision of student and staff identity cards, provision of internet facilities, advisory role to the management and provision for other support services to enhance the teaching, learning, research and efficient services of the school. The unit is headed by a director who coordinates the overall activities of ensuring that ICT services are maximize toward improved efficiency and quality output. The staff comprises of both permanent employees of the polytechnic and part-time staff mostly programmers, computer operators, computer technician and system engineers. The major facilities are located at the administrative building where (MIS), the PTDF building (cybercafé) and the main ICT centre where all activities are being coordinated from.

\subsection{Effects of ICT on the Performance of Tertiary Institutions of Learning}

The Information and Communications Technology (ICT) is the technology that has brought excitement to teaching, learning and research. It has become a major educational technology. In its simplest form, it can be used to prepare and reproduce hand-outs or make presentations of learning materials as slides in lecture rooms. At a higher level, ICT could be used in such instructional modes as e-learning. For Nigerian educational institutions, the development in the use of ICT provides an opportunity to overcome the perennial problem of non-availability of staff, books and even the lack of equipment in the laboratories (Massaquoi, 2006).

\subsection{Infrastructural Challenges of Implementing ICTs in Tertiary Institutions}

ICT is heavily dependent on appropriate technological infrastructure. Developing countries, particularly Nigeria has really embraced ICT as an instrument to enhance the quality of education, accessibility to learning resources, creating opportunities for open learning, it is worthy of note that the use of ICT in education is still faced with myriads of constraints which have restricted its efficient and effective use, it also constituted challenges to the use of ICT in education. 
ICT infrastructure which include computer hardware and software, bandwidth/access, connectivity are grossly inadequate, and have constituted constraints on its effective usage (Siddiqui, 2004).

Although ICT has the potential to improve education system of a country to a great extent, yet it is not the case in the developing countries. There are multiple issues and challenges confronting the implementation of ICT education in schools and educational institutions in these countries. Owhotu (2006) asserted the followings as constraints for ICT usage in Tertiary Institutions in Nigeria including Katsina State, this include inadequate power supply, financial constraints, inadequate/ lack of expertise, bureaucracy in administering ICT in teaching and learning periods, distance, space and time, moral and ethical values, and lack of feedback.

\subsection{Strategies for Effective Implementation of ICT}

The problems facing the teaching of ICT can easily be addressed with some strategies. Yomere and Esosa (2011) define strategy of a firm as "a well-considered pattern of resources deployment that is appropriate and adequate for achieving the desired quality and level of effective interaction with the environment". In effect, a strategy is a means to an end. It is the mechanism by which an organization deploys its resources - men, material, machines, financial - to execute a plan of action that has been laid out to achieve an objective efficiently and effectively. Ugwuanyi and Eze (2009) identify the strategies for enhancing the teaching of ICT in Business Education as availability of adequate computers on the basis of one student to one computer during class sessions, provision of reprographic machines such as photocopiers and duplicators, micrographics such as microfilming machines, electronic communication equipment such as e-mail, facsimile (FAX), telex machines, word processing laboratories fitted with air conditioners and good lighting, office practice laboratories equipped with modern office equipment, audio visuals, chalkless boards and stand-by generating sets.

Ejiofor and Osinem (2010) also suggest some strategies for enhancing the teaching of ICT in Nigerian universities: students and teachers must have sufficient access to digital technologies and internet in their classrooms; schools and teacher education institutions; high quality, meaningful, and culturally responsive digital content must be available for teachers and learners; teachers must have the knowledge and skills to use the new digital tools and resources to help all students' achieve high academic standards; Egboka (2012) notes these strategies for enhancing the teaching of ICT, the management of universities should build stronger links with multinational businesses and other external stakeholders to assist them in providing ICT facilities in their universities; the universities' portals should be used to disseminate updated university policy statements to staff, students and interested public; the management of the universities should develop legal and policy frameworks that stipulate their rationale for ICT empowerment in their institutions (Egboka, 2012).

\subsection{Barriers to Effective Implementation}

Cognisant of the substantial opportunities that ICT can provide universities, there are a number of problems and challenges that tend to present themselves. Universities are confronted with outside problems coming from their environment, as well as with inside problems coming from their own structure and culture (Loing, 2005). In Africa for instance, there are issues that have to do with national policies and plans. Many of the countries do not have national ICT policies. This leads to situation where each university has to do what it knows best to do without a central coordinating document. The presence of an ICT policy in a country cannot be overemphasized as it goes a long way to streamline ICT implementation across institutions - private or public. The problem of ICT policy brings to the fore the issue of restrictive regulatory framework. Luboobi (2007) observes that the regulatory frameworks for the telecommunications, ICT and intellectual property rights are still restrictive in most African countries.

Another major outside issue that seems to have plagued ICT implementation in universities is the problem of Bandwidth. The high cost of bandwidth, inadequate and unreliable telecommunication services and applications still remains a major challenge. There is also the problem of insincerity on the part of service provider. Many universities are being made to pay for an amount of bandwidth that is never supplied to them. Until they come to the point of having a dedicated pipe for direct supply the issue of surcharging them may never end. It is hoped however, that with the launching of NIGCOMSAT - 1 by Nigeria the cost of securing bandwidth might be brought down particularly for Nigeria universities. There is also the problem of political instability. Luboobi (2007) observes that Africa is the most unstable continent and its countries are still young democracies. According to him political unrest is a major threat to staff retention and institutional stability. Such instability frustrates policies and plans, and therefore, stagnate developments with all its ramifications (Luboobi, 2007).

Within Universities themselves, Loing (2005) indicates that the implementation of ICT is not an easy task for faculty and staff members, as decision makers and academics are sometimes reluctant to change curricula and pedagogical approaches. Teaching staff and instructors lack incentives and rewards in a system where professional status and career trajectories are based on research results rather than pedagogic innovation. This obvious lack of incentives, perhaps underlies the unwillingness to implement initiatives related to ICT implementation in teaching and learning. Other problems/ challenges relate to infrastructure, staff retention, and computer illiteracy among staff and students. Luboobi observed that the African continent lack a continent wide-wide broadband optical fibre network. However, he points out that under NEPAD, there are plans to establish the broadband ICT network for Africa. Though some universities in the region like Makerere University and University of Jos have optical fibre backbone they are not linked to any national bank ICT. There is a major problem of acquisition of ICT facilities such as computers and printers and undertaking viable networking (LAN \& WAN) activities within university campuses. Most universities are grossly underfunded and therefore not enabled to sustain the infrastructure required for securing viable ICT facilities in the current ICT-driven world (Loing, 2005). 


\section{Methodology}

The target population in the study constitute 2,360 teaching staff and non-teaching staff from the three selected tertiary Institutions (Kogi State University Anyigba, Kogi State College of Education Ankpa, and Federal Polytechnic Idah) in Kogi East Senatorial District. The sample size for this study comprises of 331. The sample size was reached using Krejcie \& Morgan sample size determination table.

However, the 331 sample size will be proportionately distributed using the formula below:

Sample population x Sample size

Total population

For Kogi State University, Anyigba

$\underline{873 \times 331}$

$2360=122$

For Federal Polytechnic, Idah

868x 331

$2360=112$

For Kogi State College of Education, Ankpa $\quad \underline{619 \times 331}$

$2360=89$

Therefore, the sample size is, $122+122+89=331$

\section{Analysis of Data}

\begin{tabular}{|c|c|c|}
\hline Option & Frequencies & Percentage (\%) \\
\hline Strongly agree & 123 & 39.94 \\
\hline Agree & 167 & 54.22 \\
\hline Undecided & 8 & 2.60 \\
\hline Disagree & 5 & 1.63 \\
\hline Strongly & 5 & 1.63 \\
Disagree & & \\
\hline Total & 308 & 100 \\
\hline
\end{tabular}

Table 1: Respondents View on the Adoption of ICT by Institutions Source: Field Survey, 2018

Table 1 above indicates that the use of ICT has been adopted by the institutions has 123(39.94\%) and 167(54.22\%) strongly agree and agree respectively that ICT has been adopted by the institution. This aid the researcher a confidence in the outcome of this research as the institutions under investigations has adopted ICT as a means to ease the work and make efficient result in the institution.

\begin{tabular}{|c|c|c|}
\hline Option & Frequencies & Percentage (\%) \\
\hline Strongly agree & 87 & 22.28 \\
\hline Agree & 55 & 17.86 \\
\hline Undecided & 25 & 8.12 \\
\hline Disagree & 122 & 39.61 \\
\hline Strongly Disagree & 19 & 6.17 \\
\hline Total & 308 & 100 \\
\hline
\end{tabular}

Table 2: Respondents View on Adequacy of ICT

Facilities Available in the Institution

Source: Field Survey, 2018

Data on Table 2 shows that there are no adequate ICT facilities in the institutions under investigation as $122(39.61 \%)$ and $19(6.17 \%)$ of the respondents disagree and strongly disagree respectively that the institution have adequate ICT facilities, $87(22.28 \%)$ and $55(17.86 \%)$ strongly agree and agree that the institution have adequate ICT facilities while the remaining $25(8.12 \%)$ of the total respondents are undecided about this question.

\begin{tabular}{|c|c|c|}
\hline Option & Frequencies & Percentage (\%) \\
\hline Strongly agree & 75 & 24.35 \\
\hline Agree & 159 & 51.63 \\
\hline Undecided & 23 & 7.47 \\
\hline Disagree & 42 & 13.64 \\
\hline Strongly Disagree & 9 & 2.93 \\
\hline Total & 308 & 100 \\
\hline
\end{tabular}

Table 3: Respondents View on Whether ICT Has Helped the Institution to Meet the Set Targets

Source: Field Survey, 2018 
Data on Table 3 shows that ICT has really helped the institutions to meet the set target in the institutions over the years as $159(51.63 \%)$ and $75(24.35 \%)$ of the respondents agree and strongly agree that ICT has helped the institution to meet the set targets. While $42(13.64 \%)$ and $9(2.93 \%)$ of the respondents opined that there are still some target not yet meet by the presence of ICT.

\begin{tabular}{|c|c|c|}
\hline Option & Frequencies & Percentage (\%) ) \\
\hline Strongly agree & 28 & 9.09 \\
\hline Agree & 104 & 33.77 \\
\hline Undecided & 26 & 8.45 \\
\hline Disagree & 102 & 33.11 \\
\hline Strongly Disagree & 48 & 15.59 \\
\hline Total & 308 & 100 \\
\hline
\end{tabular}

Table 4: Respondents View on Effect of ICT on Administrative Activities Source: Field Survey, 2018

Data on Table 4 shows that though ICT has made significant improvement in the institutions but still have space of improvement on the academic and administrative activities of tertiary institution as $28(9.09 \%)$ and $104(33.77 \%)$ of the respondents strongly agree and agree respectively that ICT has not made significant improvement on the academic and administrative activities in tertiary institution while $102(33.11 \%)$ and $48(15.59 \%)$ of the total respondents also strongly disagree and disagree respectively stating that ICT has made significant improvement on the academic and administrative activities in tertiary institution.

\begin{tabular}{|c|c|c|}
\hline Option & Frequencies & Percentage (\%) \\
\hline Strongly agree & 39 & 12.67 \\
\hline Agree & 93 & 31.17 \\
\hline Undecided & 29 & 9.42 \\
\hline Disagree & 121 & 39.29 \\
\hline Strongly Disagree & 31 & 10.07 \\
\hline Total & 308 & 100 \\
\hline
\end{tabular}

Table 5: Respondents View on Whether There Is Adequate ICT Infrastructure in Institution under Study Source: Field Survey, 2018

Table 5 indicates that $121(39.29 \%)$ and $31(10.07 \%)$ of the respondents indicated that there is no adequate ICT infrastructures in the institutions, while $39(12.67 \%)$ and $93(31.17 \%)$ of the total respondents opined that the available ICT infrastructure are adequate to effect the development needed by the institutions.

\begin{tabular}{|c|c|c|}
\hline Option & Frequencies & Percentage (\%) \\
\hline Strongly agree & 53 & 17.21 \\
\hline Agree & 155 & 50.32 \\
\hline Undecided & 23 & 7.47 \\
\hline Disagree & 57 & 18.51 \\
\hline Strongly Disagree & 20 & 6.49 \\
\hline Total & 308 & 100 \\
\hline
\end{tabular}

Table 6: Frequency Respondents View on Whether the Availability of ICT

Infrastructures Has Helped in Efficient and Effective Administrative Duties in Your Institution Source: Field Survey, 2018

Data on Table 6 shows that about $67.53 \%$ of the respondents believed that the availability of ICT infrastructures has helped in efficient and effective administrative duties in these institutions while about $25 \%$ of the total response said the availability of ICT infrastructures has not helped in efficient and effective administrative duties in these institutions.

\begin{tabular}{|c|c|c|}
\hline Option & Frequencies & Percentage (\%) \\
\hline Strongly agree & 15 & 4.87 \\
\hline Agree & 94 & 30.52 \\
\hline Undecided & 23 & 7.47 \\
\hline Disagree & 132 & 42.86 \\
\hline Strongly Disagree & 44 & 14.29 \\
\hline Total & 308 & 100 \\
\hline
\end{tabular}

Table 7: Frequency Distributions of Respondents View on Whether the Available ICT Infrastructures in Your Institution Are Effective Source: Field Survey, 2018 
Data on Table 7 shows that $132(42.86 \%)$ and $44(14.29 \%)$ of the staff respondents believed that not all the available ICT infrastructures in these institution are effective while 15 (4.87\%) and 94 (30.52\%) strongly agree and agree that all the available ICT infrastructures in your institutions are effective.

\begin{tabular}{|c|c|c|}
\hline Option & Frequencies & Percentage (\%) \\
\hline Strongly agree & 27 & 8.77 \\
\hline Agree & 117 & 37.99 \\
\hline Undecided & 40 & 12.99 \\
\hline Disagree & 99 & 32.14 \\
\hline Strongly Disagree & 25 & 8.12 \\
\hline Total & 308 & 100 \\
\hline \multicolumn{2}{|c|}{ Table 8: Respondents View on Whether the Available ICT } \\
Infrastructures Are Not Fully Utilized \\
Source: Field Survey, 2018
\end{tabular}

Data on Table 8 shows that available ICT infrastructures are not fully utilized. This is concluded as 27 (8.77\%) and $117(37.99 \%)$ strongly agree and agree that available ICT infrastructures are not fully utilized, this coincides with the findings of Akankwasa (2006) which says although many teachers beliefs that educational technology should promote learning and that the use of ICT is desirable, ICT infrastructures are not yet fully utilize because of expertize needed to utilize such resources may not be readily available.

\begin{tabular}{|c|c|c|}
\hline Option & Frequencies & Percentage (\%) \\
\hline Strongly agree & 42 & 13.64 \\
\hline Agree & 148 & 48.05 \\
\hline Undecided & 37 & 12.01 \\
\hline Disagree & 51 & 16.56 \\
\hline Strongly Disagree & 30 & 9.74 \\
\hline Total & 308 & 100 \\
\hline
\end{tabular}

Table 9: Frequency Distributions of Respondents View on Whether the Available ICT

Infrastructures Has Not Helped to Achieve the Purpose for the Adoption of ICT In Tertiary Institutions in Kogi East

Source: Field Survey, 2018

Table 9 above shows that since the available ICT infrastructure are under-utilized, It (the available ICT infrastructures) has not also helped to achieve the purpose for the adoption of ICT in tertiary institutions in Kogi East.This is proven as 42 (13.64\%) and 148 (48.05\%) strongly agree and agree respectively thatthe available ICT infrastructures has not helped to achieve the purpose for the adoption of ICT in tertiary institutions in Kogi East.

\begin{tabular}{|c|c|c|}
\hline Option & Frequencies & Percentage (\%) \\
\hline Strongly agree & 11 & 3.57 \\
\hline Agree & 36 & 11.69 \\
\hline Undecided & 29 & 9.42 \\
\hline Disagree & 146 & 47.40 \\
\hline Strongly & 86 & 27.92 \\
Disagree & & \\
\hline Total & 308 & 100 \\
\hline
\end{tabular}

Table 10: Frequency Distributions of Respondents View on Whether the Adoption of ICT Infrastructures by Tertiary Institutions in Kogi

East Amounts to Waste of Resources Source: Field Survey, 2018

Data on table 10 shows that the adoption of ICT infrastructures by tertiary institutions in Kogi East is not a waste of resources as opined by $146(47.40 \%)$ and $86(27.92 \%)$ of the total respondents this shows a good percentage in the distribution and this also help the institution management to evaluate the perception of staff over the provision of ICT infrastructures in the institutions. 


\begin{tabular}{|c|c|c|}
\hline Option & Frequencies & Percentage (\%) \\
\hline Strongly agree & 20 & 6.49 \\
\hline Agree & 84 & 27.27 \\
\hline Undecided & 47 & 15.26 \\
\hline Disagree & 126 & 40.91 \\
\hline Strongly Disagree & 31 & 10.06 \\
\hline Total & 308 & 100 \\
\hline
\end{tabular}

Table 11: Frequency Distributions of Respondents View That Most of the

ICT Infrastructures Available Are Outdated

Source: Field Survey, 2018

Data on Table 11 shows that relevant percentage of infrastructures are up to date as they were recently supplied or renewed as stated by $126(40.91 \%)$ and $31(10.06 \%)$ of the total respondents in disagree and strongly disagree respectively on the view that most of the ICT infrastructures available are outdated, $20(6.49 \%)$ and $84(27.27 \%)$ of the total respondents strongly agree and agree that most of the ICT infrastructures available are outdated while the remaining $47(15.26 \%)$ of the staff respondents were undecided about the question at the time of filling this report.

\begin{tabular}{|c|c|c|}
\hline Option & Frequencies & Percentage (\%) \\
\hline Strongly agree & 147 & 47.73 \\
\hline Agree & 120 & 38.96 \\
\hline Undecided & 18 & 5.84 \\
\hline Disagree & 11 & 3.57 \\
\hline Strongly Disagree & 12 & 3.90 \\
\hline Total & 308 & 100 \\
\hline Table 12: Frequency Distributions of Respondents View on \\
Whether the ICT Provides Easy Access to More Extensive and Current Information \\
Source: Field Survey, 2018
\end{tabular}

Data on Table 12 shows that ICT provides easy access to more extensive and current information as 147 (47.73\%) of the respondents strongly agree to this backed by 120 (38.96\%) of the respondents which also agree that ICT provides easy access to more extensive and current information in the institution under study.

\begin{tabular}{|c|c|c|}
\hline Option & Frequencies & Percentage (\%) \\
\hline Strongly agree & 43 & 13.96 \\
\hline Agree & 112 & 36.36 \\
\hline Undecided & 27 & 8.77 \\
\hline Disagree & 94 & 30.52 \\
\hline Strongly Disagree & 32 & 10.39 \\
\hline Total & 308 & 100 \\
\hline
\end{tabular}

Table 13: Frequency Distributions of Respondents View on

Whether the Level of Performance of the Available ICT Infrastructure in

Institutions Is Encouraging

Source: Field Survey, 2018

Table 13 above shows that the level of performance of the available ICT infrastructure in these institutions are encouraging, this is proven by $43(13.96 \%)$ and $112(36.36 \%)$ of the total respondents which strongly agree and agree respectively while $94(30.52 \%)$ and $32(10.39 \%)$ disagree and strongly disagree respectively that the level of performance of the available ICT infrastructure in these institutions are encouraging, believing that the performance of the available ICT infrastructure in the institution can still achieve more.

\subsection{Major Findings}

The major findings of this paper are discussed below

The study revealed that there are no adequate ICT facilities in the institutions under investigation, particularly no adequate internet connectivity (wifi), no constant or steady power supply is available to aid effective utilization of ICTs in these institutions, no adequate internet radios in Faculties, Departments and Units in institutions under studies and no functional staff e-mail services for effective communication in these institutions. This was in agreement with (Siddiqui, 2004) who stated that ICT infrastructure which include computer hardware and software, bandwidth/ access, connectivity are grossly inadequate, and have constituted constraints on its effective usage.

The study further revealed that, not all the available ICT infrastructures in these institutions are effective and available. The available ICT infrastructures are not fully utilized. This was in agreement with Siddiqui (2004) who posited reasons for low usage of ICT in education thus insufficient numbers of computers, lack of release time for teachers or lecturers to learn how to use computers or the internet and lack of time in schedule for students to use computers in class. 
The finding was also in agreement with (Loing, 2005) who posited that most universities are grossly underfunded and therefore not enabled to sustain the infrastructure required for securing viable ICT facilities in the current ICT-driven world (Loing, 2005).

It was also in agreement with Aryatuha (2007) who noted that the availability of computer hardware and software should be accompanied with training of the users and constant technical support. Without this, even though high quality hardware and software are available, they could be wasted or remain underutilized by the users.

\section{Conclusion}

In conclusion, the study shows that there are no adequate ICT facilities in the institutions under investigation, particularly no adequate internet connectivity (wifi), no constant or steady power supply is available to aid effective utilization of ICTs in these institutions, no adequate internet radios in Faculties, Departments and Units in institutions under studies and no functional staff e-mail services for effective communication in these institutions, not all the available ICT infrastructures in these institutions are effective and efficient, the available ICT infrastructures are not fully utilized.

\section{Recommendations}

- Tertiary institutions should make available adequate ICT facilities in the institutions, particularly adequate internet connectivity (wifi), constant or steady power supply to aid effective utilization of ICTs in these institutions, adequate internet radios in Faculties, Departments, Directorates and Units in institutions under study and functional staff e-mail services for effective communication in these institutions.

- All the available ICT infrastructures in these institutions should be effectively and efficiently utilized. This is because, ineffective utilization of some ICT infrastructures culminates in their decay and malfunctioning.

\section{References}

i. Abascal, J. \& Nicolle, C. (2005). Moving towards inclusive design guidelines for socially and ethically aware HCI. In special issue of interacting with computers: Social impact of emerging technologies, 17(5): Elsevier B.V., 484-505.

ii. Abimbade, A. (2002). Perspective of technology integration and effectiveness of computer assisted instruction (CAI) in primary mathematics classroom, Unique research chronicle, 4(2): 88-107.

iii. Achimugu, H., Chukwurah, D.C., \& Ochala, M. (2013), Repositioning Nigerian local governments for better performance: What potential does the E-Government option hold? IOSR Journal of humanities and social science (IOSR-JHSS) Vol. 12 (2) www.Iosrjournals.Orgwww.iosrjournals.org.

iv. Achimugu, P., Oluwagbemi, O., \& Oluwaranti, A. (2010). An evaluation of the impact of ICTs diffusion in Nigeria's higher educational institutions. Retrieved on 11 March, 2013, from www.jiti.com/ ../ jiti.V10n1.025034

v. Achonna, A.U. \& Yaya, J. A. (2008): ICT register and internet usage in libraries. In N.E. Achebe (ed). Library and information literacy for higher education (pp.164-189). Enugu: NLA state chapter.

vi. Adavbiele J. A., (2016). The use of ICT to enhance university education in Nigeria. International Journal of Education, Learning and Development, 4, (5), 1-11

vii. Adeogun, M. (2003). The digital and university education systems in sub-Saharan Africa. African Journal of Library, Archival, and Information Science, 13(1): 11-20.

viii. Adeyemi, I.I. \& Esere, M. (2013). ICT and higher educational system in Nigeria. Educational Research Reviews 8(21): $2021-2025$

ix. Adeyemi, T.O. \& Olaleye, F.O. (2010). Information Communications and Technology (ICT) for the effective management of secondary schools for sustainable development in Ekiti state, Nigeria. Retrieved on 10 March, 2013, from www.idosi.org/ aejsr/ 5(2)10/ 4.pdf. PP.106-9.

x. Adomi, E. E., Omodeko, F.S. \& Otolo, P.U. (2003). A survey of cyber cafes in Delta state Nigeria. The Electronic Library 21 (5): 487-495.

xi. Adoni, E.E. (2006): Mobile Phone Usage patterns of Library and Information Science students at Delta State University, Abraka, Nigeria. Electronic Journal of Academic and Special Librarianship. 7(1).

xii. Agbetuyi, P.A. \& Oluwatayo, J.A. (2012). Information and Communications Technology (ICT) in Nigerian educational system. Mediterranean Journal of Social Sciences; Vol.3.

xiii. Ajzen I. (1991). The theory of planned behavior. Organizational behaviour and human decision processes 50(2), 179-211.

xiv. Ajegbelen, A.J. (2016). The use of ICT to enhance university education in Nigeria. International Journal of Education, Learning and Development 4(5):1-11. Published by European centre for research training and development UK.

xv. Akankwasa, P. (2006). Teachers' attitudes toward information and communication technologies. Journal of Computer and Education, 47, 373-398

xvi. Akankwasa, P. (2008). Problems affecting the level of computer use for instructional purposes by technology teachers in government schools in Uganda. Unpublished Bachelors" research, Uganda Christian University, Mukono, Uganda.

xvii. Akinsola, O. S., Herselman, M. E. \& Jacobs, S. J. (2005): ICT provision to disadvantage urban communities. A study in South Africa and Nigeria. International Journal of Education and Development using Information and Communication Technology (IJEDICT) 1(3), pp. 19-41. 
xviii. Akir, Z.I. (2006). Impact of Information and Communication Technology on teaching and training:A qualitative systematic review. Unpublished $\mathrm{PhD}$ dissertation, Ohio University.[Online]Availableat: http:/ / www.ohiolink.edu/ etd/ send- pdf.cgi?ohiou1145903498.

xix. Al-Ansari, H. (2006). The internet use by faculty members of Kuiat University. The Electronic Library, 26(6):791803.

xx. Aliyu, M. (2007): Use of information communication technology in information networking among national scientists in Ahmadu Bello University, Zaria. Global review of library and information science, 3, 13 - 23.

xxi. Altman, D.G. (2003) Practical Statistics for Medical Research. Chapman \& hall/ CRC, Malawi Medical Journal. 24(3) pp. 67-71.

xxii. Amin, M. E. (2005). Social science research: conception, methodology and analysis. Kampala: Makerere university printer.

xxiii. Amichai-Hamburger,Y. (2009). Technology and psychological well-being, Cambridge, New York, Melbourne: Cambridge university press.

xxiv. Anan, K. (2002): Globalization and governance: the role of U. N. in the 21st century. New York: UN dept. of publication.

xxv. Anansi, S.M. (2005): Multidimensional interventions of information and communication technologies for women empowerment in Nigeria. Journal of Library and Information Science (LATLIS), 3 (1), 36-66.

xxvi. Anunobi, C. V. \& Edoka, B. E. (2010): Use of ICT facilities for serials functions in southern Nigeria federal university libraries. Library philosophy and practice (April) pp. 1-10.

xxvii. Aryatuha, H. (2007). Relationship between computerization and organizational effectiveness in day-day running of business at MOH headquarters in Kampala. Unpublished masters' dissertation, Makerere University, Kampala, Uganda.

xxviii. Atanasoff, J.V. (1973). Computing machine for the solution of large systems of linear algebraic equations, in the origins of digital computer, selected papers, ed. Brian Randell, Chap. 7.2. New York.

xxix. Bakkabulindi, F. (2008). Individual characteristics affecting use of computers in Makerere University. Unpublished research guidelines for masters' students (Educ). Makerere University, Kampala, Uganda.

xxx. Baym, N. (2010). "Personal connections in the digital age". Cambridge: polity press, 2010. p.24

xxxi. Benbasat I. and Barki H (2007) Quo vadis TAM? Journal of the Association for Information Systems 8(4), 211-218.

xxxii. Bemah, G. B. (2002). Internet information resources usage among undergraduates at the University of Ibadan, unpublished thesis, university of Ibadan, Nigeria.

xxxiii. Bimber, B (May 1990). "Karl Marx and the three faces of technological determinism". Social Studies of Science. 20 (2):333-351. doi:10.1177/ 030631290020002006

xxxiv. Borgmann, A. (1994). Across the postmodern divide Chicago: University of Chicago Press.

xxxv. Brock, D.B., \& Sulsky, L.M. (1994). Attitudes toward computers: Construct validation and relations to computer use. Journal of Organisational Behaviour, 15(1), 17 - 35.

xxxvi. Charles, B.A. (February 1927). "Time, Technology, and the Creative Spirit in Political Science". The American Political Science Review. 21 (1): 1-11. doi:10.2307/ 1945535. JSTOR 1945535

xxxvii. Creswell J.W. (2003). A framework for design in Research design: qualitative, quantitative and mixed methods. CA: Sage Publications, Thousand Oaks, CA.

xxxviii. Curtin, K.D. (2002). Gap junction proteins expressed during development are required for adult neural function in the Drosophila optic lamina. J. Neurosci. 22(16): 7088--7096.

xxxix. Dabla A., (2004): "The role of IT Policies in promoting social and economic development: The case of the state of Andhra Pardesh, India," EJISDC 19, 2004, 5, 1-21.

xl. Davies, G.K. (1995, June). Higher education's big problems: Can technology help resolve them? Keynote address delivered at the semi-annual meeting of the Education National Learning Initiative. Keystone, CO.

xli. Davis, F. G. (1989). The Technology Acceptance Model. Retrieved 5th April 2017 at 10:37am from http:/ / www.citevlike.org/ user/ cite/ man/ article/ 5428229.

xlii. Davis, J., Foxall, G. \& Pallister, J. (2002). Beyond the intention-behavior mythology: An integrated model of recycling, Marketing Theory 2 (1), pp.29-113.

xliii. Dick, P. (2003): Penguin Dictionary of Computing. Australia: Penguin Published

xliv. Dickson, O.I. (2012). The Role of ICT Development in Open and Distance Education: Achievements, Prospects and Challenges, African Journal of Teacher Education, 2(2): 23-30.

xlv. Doss, C. R \& Morris, M. L. (2001). How does gender affect the adoption of agricultural innovation? The case of improved maize technologies in Ghana. Journal of Agricultural Economics, 25, 27-39.

xlvi. Dotimi, D.A. \& Hamilton-Ekeke, J-T. (2013) Information and Communication Technology (ICT) - E-Learning in Nigerian Tertiary Institutions, the Librarian and Information Manager 6(1): 44-59.

xlvii. Dzidonu, A. (2010). The Role of ICTs to Achieving the MDGs in Education: An Analysis of the Case of African Countries. Accra Ghana.

xlviii. Economic Commission for Africa (ECA) (2008): Retrieved from http:www.uneca.orgieca programmes/-fordevelopment/ default.html.

xlix. Egboka, P. N. (2012). The status of information and communications technology (ICT) in empowering policy implementation in universities in south east zone of Nigeria. International Journal of Educational Research and Development, 8(2), 231-236. 
l. Ejiofor, T. E., \& Osinem, C. E. (2010). Emerging roles of information and communication technology (ICT) in the implementation of agricultural teacher education programme in tertiary institution in Anambra and Enugu state of Nigeria. Journal of Vocational and Adult Education, 7(1), 14-24.

li. Ehikhamenor, F. A. (2002). Internet resources and productivity in Nigerian Universities. Journal of Information Science, 29 (2): 107-115.

lii. Ekeke, H. J. T. \&Mbachu C. E. (2015): The Place of Information, Communication and Technology (ICT) in Teaching and Learning in Nigerian Tertiary Institutions. American Journal of Educational Research, 20153 (3), pp 340-347.

liii. Emmanuel, S.M. (2015). Utilization of Information and Communication Technologies (ICTs) in Public Library Services in Nigeria. Ph.D Thesis, Department of Library and Information Science, University of Nigeria, Nsukka (UNN).

liv. Encyclopedia Britannica (2003): http:/ / www.britannica.com.

lv. Ensafi, R., Zamiri, A. \& Kahani, M. (2007). ICT challenges in education. Reflections from a developing country: Iran, with reference to the statistics from computer science students. The 2nd International Conference on Virtual Learning, Ferdowsi University, Mashhad, Iran.

lvi. Etim, E.E., Akpan, I.U. \& Ibok, E. (2013). Globalization and the Educational System in Nigeria International Journal of Modern Management Sciences, 2013, 2(1): 7-17.

lvii. Feder, G \& Slade, R. (1984).The acquisition of information and adoption of new technology. American Journal of Agricultural Economics, 66: 312-20.

lviii. Feenberg, A. (2004). "Democratic Rationalization". Readings in the Philosophy of Technology. David M.K. Oxford: Rowman \& Littlefield, 210-212.

lix. Fidelis, E. Sanjay, M., Ibrahim, A. \& Ricardo, C.P. (2014): An Evaluation of ICT Infrastructure and Application in Nigeria Universities. ActaPolytechnicaHungarica, Vol. 11, No. 9, 2014.

lx. Fishbein M. \& Ajzen, I., 1989. Understanding attitudes and predicting social behavior. Englewood Cliffs, NJ: Prentice-Hall.

lxi. Genoni, P., Merrick, H. \& Willson M. A. (2006). The scholarly communities, e-research literacy and academic librarian. The Electronic Library 24(6):737-746.

lxii. Felix Q., Wolali A. \& Nana K.A. (2015). The Impact of ICT on Teaching and Learning in Tertiary Institutions: A case Study of Wisconsin International University, Ghana. Journal of Information Engineering and Applications. Vol. 5, No. 5. ISSN 2224-5782 (print) ISSN 2225-0506 (online). www.iiste.org

lxiii. FOLDOC (2008-09-19). Information and Communication Technology.

lxiv. Foros Q., Kind H.J. \& Sand J.Y. (2005). Do internet incumbents choose low Interconnection quality? Information Economics and Policy. Volume 17, Issue 2, March, Pages 149-164.

lxv. Gillwald, A. \& Esselaar, S. (2005). A Comparative Analysis of ICT Access and Usage in 10 African countries, available at http:/ / www.researchictafrica.net/ images/ upload/ Chapter02new(latest).pdf accessed March 2014.

lxvi. Global e-Schools and Communities Initiative (GeSCI) (2009). Kenya: ICT in Education Situational analysis; ministry of Education. Government printers.

lxvii. Green, Leila (2001). Technoculture: From Alphabet to Cybersex. Crows Nest: Allen \& Unwin. p. 15.

lxviii. Grossman, G. \& Helpman, E. (2005). "Outsourcing in a global economy". Review of Economic Studies. 72: 135-159

lxix. Gupta, V. \&Ansari, M. A. (2007): Impact of technology on societal development and e-governance. Electronic Journal of Academic and Special Librarianship, 8 (1).

lxx. Hamilton-Ekeke, J. T. \& Mbachu C.E. (2015). The Place of Information, Communication and Technology (ICT) in Teaching and Learning in Nigerian Tertiary Institutions. American Journal of Educational Research 3 (3): 340 347.

lxxi. Hargittai, E. (1999): "Weaving the Western Web: Explaining Differences in Internet Connectivity among OECD Countries", Telecommunications Policy, 23, 1999, 701-718.

lxxii. Higgins, S. \& Moseley, D. (2011). Teachers' Thinking about ICT and Learning: Believes and Outcomes. Journal of Teacher Development, 5 (2), pp. 191-210.

lxxiii. Hungwa S., Igyuve S. \& Nicholas T. (2015): A study of information and communication technology (ICT) skills of staff of tertiary institutions in Benue state, Nigeria. $\quad$ African Journals Online (AJOL) Vol. 12, No. 2.

lxxiv. http:/ / ehlt.flinders.edu.au/ education/ iej/ articles/ v6n4/jhurree/ paper.pdf

lxxv. https:/ / en.m.wikipedia.org/ wiki/ cross-sectional_study.

lxxvi. Iboma, J.2007. Nigerian IT development agency established by law. [Online] Available at: http:/ / www.bizcommunity.com/ Article/ 157/ 16/ 14665.html (accessed 5 July 2007).

lxxvii. ICT - What is it?".www.tutor2u.net. Retrieved 2015-09-01.

lxxviii. Igyor, G.A. (1996). The Economic and Social Benefit of Telecommunications Technology. A Paper Presented at the Animal International Conference on Information Technology Management Infotech, "96 at Sharaton Lagos Hotel, October $23-25$.

lxxix. Isham, I. (2002). The effect of social capital on fertilizer adoption: evidence from rural Tanzania. Journal of African Economies, 11(1): 39-60.

lxxx. Islam, S. \& Islam, N. (2007): Use of ICTs in libraries: an empirical study of selected Libraries in Bangladesh. Philosophy practice, annual volume.

lxxxi. Jegede O. (2002): An Integrated ICT -Support for ODL in Nigeria: The Vision, the mission and the journey so far. Being paper prepared for the LEARNTEC-UNESCO 2002 Global Forum on Learning Technology, Karlsruhe, Germany 3-8 February, 2002. Retrieved from portal.unesco.org on 8/ 9/2006. 
lxxxii. Jeremy G., Charles K. \& Christine Q. (2004): Information and Communication Technologies and Broad-Based Development. A Partial Review of the Evidence. Washington DC: World Bank Working Paper No. 12. January 2004.

lxxxiii. Joseph K.J., (2002): "Growth of ICT and ICT for Development", United Nations University, Discussion Paper No. 2002/ 78, August 2002.

lxxxiv. Justus A. T. (2011): Problems in ICT Implementation in Selected Institutions of Higher Learning in Kabale District. A dissertation submitted in partial fulfilment of the requirements for the award of the Degree of Masters of Education in Information and Communication Technology, Kampala, Uganda.

lxxxv. Kanos M., (2013). Challenges faced in Implementing ICT in Higher Learning Institutions. A Botswana perspective. International Journal for Infonomics (IJI), Vol.6, (1/2).

lxxxvi. Katundu, D. (2000). The use and sustainability of Information Technology (IT) in academic and research libraries in Tanzania. Unpublished Ph.D. Thesis. Pietermaritzburg, University of Natal.

lxxxvii. Kasozi,A. B. K. (2003). University education in Uganda. Challenges and opportunities for reform. Kampala, Fountain.

lxxxviii. Keengwe, J. \& Onchwari, G. (2011). Computer Technology Integration and Student Learning:Barriers and Promise. Journal of Science Education and Technology, 17, pp. 560-570. Available: http:/ / dx.doi.org/ 10.1007/ s10956- 0089123-5

lxxxix. Kim, E. G. (1999). Towards a holistic model for the diffusion of education technologies in USA. Educational Technology and Society, 2 (4)

xc. Kinengyere, A. A. (2007).The effect of information literacy on the utilization of electronic information and resources in selected academic and research institutions in Uganda. The Electronic Library 25(3):328-341.

xci. Kogi State University Annual Report, 2014/ 2015.

xcii. Krejcie R.V. \& Morgan D.W. (1970). Determining Sample Size for Research Activities Educational and Psychological Measurement. 30, 607-610.

xciii. Kumar, R. \& Kaur, A. (2005). Internet and its use in the Engineering Colleges of Punjab, India: A case study. Webology 2(4): 1-22.

xciv. Langdon W. (1986). "Do Artefacts Have Politics"? The Whale and the Reactor. Chicago: University of Chicago Press. p. 26.

xcv. Larose, F., David, R., Diran, J., Karsenti, T., Grenon, V., Lafrance, S. \& Cartin, J. (1999). Information and communication technology: Journey in a major Quebec university's reality. Electronic Journal of Sociology. Retrieved May 27, 2007, from http:/ / www.icaap.org/ iuicode?100.4.3.3

xcvi. Laudon, K. C. \& Laudon, J. P. (2001). Essentials of Management Information Systems.(Ed) New Jersey: Prentice Hall

xcvii. Lelia G. (2001). Technoculture: Another Term That Means Nothing and Gets Us Nowhere? First PublishedFebruary 1, Research Article.

xcviii. Librero, F. (2001, May 17 - 18). Constraints - cum - challenges in ICT education inthe Philippines. $4^{\text {th }}$ National congress of the commission on higher education, Manila Midtown hotel, Manila. http:/ / www.upou.org/ books/ fl constraints.htm

xcix. Liu, L.G. (2002): The impact of the Internet in public libraries. In O.E Gorman (ed.). Information services in an electronic environment (45-68). London: Library Association.

c. Liverpool, L.S.O., Marut, MJ., Ndam, J.N. \& Oti, D.A. (2009). Towards a Model for E Learning in Nigerian HEIs: Lessons from the University of Jos ICT Maths Initiative.

ci. Loing, B. (2005, April 6 - 8). ICT and higher education. $9^{\text {th }}$ UNESCO/ NGO collective consultation on higher education.

cii. Simpson L.C.S. (1994). Technology, Time and the Conversation of Modernity. PhD thesis. http:/ / theses.gla.ac.uk/ 2953/ .

ciii. Lu, J., C-S.Yu, C. Liu \& J.E. Yao, (2003). Technology acceptance model for wireless Internet” Internet Research: Electronic Networking Applications and Policy, 13(3), 206-222.

civ. Luboobi, L.S. (2007). University roles in meeting aspirations for ICT and economic development, Retrieved June 16, 2007 from http:/ / www foudation-partnership.org/ pubs/ leaders/ assets/ papers/ luboobisession4.pdf

cv. Mac-Ikemanjima D. (2005): E-Education in Nigeria: Challenges and Prospects. Being text of a presentation at the 8th UN ICT Task Force Meeting. Retrieved from http:/ / www.one villagefoundation.org on 21/ 10/ 2006.

cvi. Makau, B. M. (1986). Barriers to the uptake of web based technology by university lecturers. Journal of Distance Education, 16 (1), 70-84.

cvii. Malcolm, E. \& Godwyll, F. (2008). Diffusion of information communication technology in selected Ghanaian schools, Unpublished Doctoral dissertation, Ohio University, USA

cviii. Margaret, P. (1995). Social science research methods: a hand book for Africa, (2nd ed), Nairobi: Educational publishers ltd.

cix. Massaquoi J.G. (2006). Trends and advances in engineering education in Africa. Retrieved from http:/ / www.Imillionpaper.com on 28/ 1 0/ 2006.

cx. Mbulankende, J. S. (2007). An assessment of teacher training in ICT in selected universities in Uganda: A case study of post graduate diploma students in education trainees. Unpublished Masters Dissertation, Makerere University, Kampala, Uganda

cxi. McBride, S.H. \& Nagle, L.M. (1996). Attitudes toward computers: A test of construct validity. Computers and Nursing. 14(3), 164 - 170. 
cxii. Medlin, B.D. (2001). The factors that may influence a faculty member's decision to adopt electronic technologies in instruction (Doctoral dissertation, Virginia Polytechnic Institute and State University.ProQuestDigitalDissertations.

cxiii. Mogbo, T.C. (2002). Information Technology in environmental education discipline in Nigeria: Need for Improvement. Journal of Computer Literacy 3(1): 12-15.

cxiv. Mohammed, A. (2007): Automation in university libraries of Nigeria: a review. TRIM, 3 (2), 109-122.

cxv. Mohanty, L. \& Vohra, N. (2008). ICT Strategies for Schools; A guide to School Administration. New Delhi: SAGE Publication. PP 1, 34, 60 Kampala: Makerere University Printer.

cxvi. Mumatz, S. (2005). Factors affecting teachers" use of information communications technology: A review of the Literature Technology, Pedagogy and Education, 9 (3), 319-342.

cxvii. Mugisha, B. (2007). Problems affecting ICT implementation in the curriculum of core primary teachers in Kabale District. A case study of Bukinda core primary teachers" college. Unpublished Bachelors" research, Mbarara University of science and technology, Mbarara, Uganda.

cxviii. Munyantware, D. B. (2006). Problems affecting teacher's adoption of technology in classrooms in secondary schools in Kisoro District. Unpublished Bachelors" research, Uganda Christian University, Mukono, Uganda.

cxix. Murphie, Andrew, Potts, John (2003). "1". Culture and Technology, London: Palgrave p. 21.

cxx. Murray, I. (2011). ICT and change in U.K. public libraries: does training matter. Library Management, 24 (1\&2), 61 $-69$.

cxxi. Nachmis R, Mioduser D, Chen A, Tubin D \& Forkosh-Bruch A (2004) Factors involved in the implementation of pedagogical innovations using technology.

cxxii. Nigerian National Policy for Information Technology (2007): Federal Republic of Nigeria (FRN). [Online] Available at: http:/ / www.nitda.gov.ng/ document/ nigeriaitpolicy.pdf

cxxiii. Negatu, W. \& Partkh, A. (1999). The impact of perception and other factors on the adoption of agricultural technology in the Morel and Jim wo re da (district) of Ethiopia. Agricultural Economics, 21: 205-16.

cxxiv. Nisar, M. W., Munir E. U. \& Shafqat A. (2011). Usage and Impact of ICT in Education Sector: A Study of Pakistan. Australian Journal of Basic and Applied Sciences, 5(12), pp. 578-583.

cxxv. Nkanu, (2006). Traditions and Customs in Community Development: The Case of Nkanu West and Nkanu East Local Government Areas ofEnugu State, Nigeria. Journal of Education and Practice

cxxvi. Nwezeh, C. M. T. (2010): The Use of ICT in Nigerian Universities: A Case Study of Obafemi Awolowo University, IleIfe. Library Philosophy and Practice 2010. ISSN 1522-0222.

cxxvii. Nwokedi, V. C. (2007). Impact of Internet use on teaching and research activities of the academic staff of Faculty of Medical Sciences, University of Jos: A Case study. Gateway Library Journal, 10 (I): 13-22.

cxxviii. Oduma, C.A. \& Chinagolum I. (2013): Information and Communication Technology in Education: Issues, Barriers and Strengths of Synchronous ICT Media: JORIND 11(2) December, 2013. ISSN 1596-8303. www.transcampus.org/ journals; www.ajol.info/ journals/ jorind 12.

cxxix. Oduma, J. (2013). Teacher Education and Information Communication Technology, in Nwaham, C.O, Moemeke, C.D. \&Onyeagwu, F.O (Eds) In Search of Excellence in Teacher Education in The 21 st Century, Agor: CeeEmmyIyke Venture.

cxxx. Oduwole, A.A. \& Akpati C.B. (2003). Electronic services provisions in Nigerian university libraries. Nigeria Library and Information Science Review (NLISR) 20 (1 \& 2): 1-7.

cxxxi. Ogechukwu N. I. \& Osuagwu, C. C. (2009). ICT in education: Achievement so far.

cxxxii. Ojedokun, A.A \& Owolabi, E.O. (2003). Internet use for teaching and research in Botswana. African Journal of Library, Archives and Information Science, 13(1):43-53

cxxxiii. Okhiria, R.N. (2007). Challenges of information and communication technology (ICT) education in Nigerian public secondary schools. Education Research Journal 2(12); 388-391. Retrieved on the 15th February, 2015 from http:/ / www.resjournals.com/ ERJ

cxxxiv. Okonji, E.2007. 'NITDA Act 2007: Boost to technology development, says Angaye.' Daily Independent, online edition, 29 May. [Online] Available at: $\quad$ http:/ / www.independentngonline.com/ ?c $=51 \& a=27335$.

cxxxv. Oladokun L. (2012). Exploring the Benefits of ICT in Educational Sector, National Information Technology Agency, Abuja: Government Press.

cxxxvi. Ololube, N. P. (2007). The relationship between funding, ICT, selection processes, administration and planning and the standard of science teacher education in Nigeria. Asia-Pacific Forum on Science Learning and Teaching, 8(1), Article 4. [Online]http:/ / www.ied.edu.hk/ apfslt/ v8_issue1/ ololube/ .

cxxxvii. Ololube, N. P. (2008) Computer communication and ICT attitude and anxiety among higher education students. In A. Cartelli, (Ed). Encyclopedia of Information and Communication Technology, pp.100-105. Hershey, PA: Idea Group Publishing.

cxxxviii. Ololube, N.P., Eke, P., Uzorka, M.C., Ekpenyong, N.S. \& Nte, N.D. (2009) Instructional technology in higher education: A case of selected universities in the Niger Delta, Asia-Pacific Forum on Science Learning and Teaching, 10(2) Article 7.

cxxxix. Onyeneke, C.O. (2007): Information and communication technology in Library and information services in tertiary institutions in Nigeria. Heartland Journal of Library and Information Science, 1 (2), 50 - 63.

cxl. Organisation for Economic Cooperation and Development (OECD)(2001). Understanding the Digital Divide. [Online] Available at: http:/ / www.oecd.org/ internet/ interneteconomy/ 1888451.pdf 
cxli. Owhotu, B. V. (2006). An Introduction to Information and Communication Technologies in Education. Lagos; Sibon Books. PP vii, 97, 104-6, 113, 123-5, 177, 167, 203

cxlii. Oyedum, G.U. (2006). Internet utilization and satisfaction by students' of Federal University of Technology, Minna, Nigeria. Borno Library, Archival and Information Science Journal 5(2):1-9.

cxliii. Parisot, A.H. (1995). Technology and teaching: The adoption and diffusion of technological innovations by a community college faculty (Doctoral dissertation, Montana State University, 1995). ProQuestDigitalDissertations.(UMI No.AAT 9542260).

cxliv. Peansupap, V. \& Walker, D. H. T. (2005). Factors enabling information and communication technology diffusion and actual implementation in construction organisations, Australia. http:/ / www.itcon.Org. Kampala: Makerere University Printer.

cxlv. Peeraer, J. \& Petergem, P. (2011). ICT in Teacher Education in an Emerging Developing Country:Vietnam's Baseline Situation at the Start of the Year of ICT. Journal of Computers \& Education, 56, pp. 974-982. Available: http:/ / dx.doi.org/ 10.1016/ j.compedu.2010.11.015

cxlvi. Philip A., Oluwagbemi O. \& Oluwaranti A. (2010) An Evaluation of the Impact of Information and Communication Technologies Diffusion in Nigeria's Higher Educational Institutions, Journal of Information Technology Impact 10 (1) pp. 25-34.

cxlvii. Ramzan, M. (2004). Does level of knowledge impact librarians' attitude toward information technology (IT) applications? 2nd International CALIBER-2004, New Delhi, 11-13 February.

cxlviii. Rebecca, W. \& Marshall, S. (2012). A New Face of Education: Bring Technology into the Classroom in the Developing World. Global Economy and Development, Brookings

cxlix. Republic of Uganda (2002). Information Technology Trends, http/ / www.ngplains.org/ documents\%5cInformation_Technology_Trends.pdf..

cl. Republic of Uganda (2007). National Information and Communication Technology Policy. Kampala, Uganda

cli. Richards, Barry. "Technophobia and Technophilia." British Journal of Psychotherapy 10.2 (1993): 188-95.

clii. Rogers, E. M. (1983). Diffusion of Innovations. New York, NY: The Free Press.

cliii. Rogers, E. M. (2003). Diffusion of Innovations. (5th ed). New York, NY: The Free Press. 100

cliv. Rogers, E.M. (1995). Diffusion of innovations. 5th edition. The Free Press. New York.

clv. Royal Society, Shut down or restart? The way forward for computing in UK schools, 2012, page 18.

clvi. Sahin, I. (2006). Detailed review of Roger's diffusion of innovations theory and educational technology. The Turkish Online Journal of Educational Technology, 5 (1), 1303-6521.

clvii. Salau, A. A. (2010): The Nigerian Air Force and information and communication technology development. Challenges and prospects. Unpublished NIPSS SEC Project.

clviii. Salih, U. (2004). Factors affecting the application of information and communication technologies in distance education in Turkey. Turkish Online Journal of Distance Education, 5 (1).

clix. Sallai Gy. (2012): The Cradle of the Cognitive Info communications, Acta Polytechnica Hungarica, 9(1), pp. 171181.

clx. Saunders, M., Lewis, P. \& Thorndike, A. (2003). Research methods for business students. 3rd ed. Pearson education limited, New Delhi.

clxi. Sayed, Y (2001): The Segregated information highway: Information literacy in higher education. University of Cape Town. Retrieved 28th Sept. 2013. http:/ / www.gse.uce.edu/ markkw/ papers.html.

clxii. Shahriza, K., Nor, A. \& Hasan A. (2007). Reading habits and attitude in digital age: Analyses of gender and academic program differences in Malaysia. The Electronic Library 25(3):285-297.

clxiii. Schwarz A. \& Chin W. 2007. Looking forward: toward an understanding of the nature and definition of IT acceptance. Journal of the Association for Information Systems 8(4), 230-243.

clxiv. Sharples, M., Arnedillo Sánchez, I., Milrad, M. \& Vavoula, G. (2007). Mobile Learning: Small devices, Big issues, available at:http:/ / www.uio.no/ studier/ emner/ matnat/ ifi/ INF5790/ v12/ undervisningsmate riale/ articles/ KAL_Legacy_Mobile_Learning_(001143v1).pdf accessed January 2014.

clxv. Siddiqui, M.H. (2004). Technology in Teacher Education. New Delhi: APH Publishing Corporation. PP 14-15, 24

clxvi. Slouka, M(1995) War of theWorlds. New York: Harper andRow.

clxvii. Smith D. \& Marx, M.\&Roe L. (June 1994). Does Technology Drive History? The Dilemma of Technological Determinism. The MT Press.

clxviii. Smith, A. (1987). Information technology and the myth of abundance in evolution of an information society. London: (N. P.).

clxix. Sylvester O. A. (2011): The Economic and Social Benefits of ICT Policies in Nigeria. Library Philosophy and Practice 2011, Delta State Polytechnic, Ozoro, Nigeria.

clxx. Republic of Ghana. The Ghana ICT for Accelerated Development (ICT4AD) Policy (2003)

clxxi. Tahir, H. (2012). Catch-up in ICT standards: Policy, implementation and standards-setting in South Korea. Technological Forecasting and Social Change, 79(4): 771-788

clxxii. Tenner, Edward. "Confessions of a Technophile." Raritan 22.1 (2002): 135 
clxxiii. Teeni D (2007) Human Computer Interaction. Hoboken, NJ, John Wiley.

clxxiv. Tinio, V. L. (2002). ICT in education. Available: http:/ / www.eprimers.org.

clxxv. Torkman, P. \& Baloh, P. (2008): Use of a model for information technology education. Journal of information technology education. 2(1) PP. 379 - 392.

clxxvi. Towards Compulsory Computer Education. Journal of Education Systems, Research and development, 1(2), 75 85.

clxxvii. Turkle, Sherry (1995) Life on the Screen. Identity in theAge of the Internet.

clxxviii. Tusubira, F. \& Mulira, N. (2004). Integration of ICT in organizations: Challenges and best practice recommendations based on the experience of Makerere University and other organizations, Paper presented at the International ICT Conference held at Hotel Africana, Kampala, Uganda. 5th to 8th September, 2004.

clxxix. Uche, C.M. \& Nwabueze, A. I. (2011). Developing Global Partnership with Nigerian Secondary School Systems through Information and Communication African Journal of Education and Technology, Volume 4 Number 1 (2014), pp. 59-69.

clxxx. Ugwuanyi, M. O., \& Eze, M. E. (2009). Strategies for effective implementation of ICT driven curriculum for secretarial studies programme in Nigerian polytechnics. Business Education Journal, 7(1), 62-80.

clxxxi. Umar M. A. (2015). Assessment of the use of Information and Communications Technology (ICT) in Tertiary Institutions in Katsina State, Nigeria.M. Ed. Thesis, Department of Educational Foundations and Curriculum, Faculty of Education, Ahmadu Bello University, Zaria,Nigeria

clxxxii. VanAkkeren J. \& Harker, D., (2003). The mobile Internet and small business: An exploratory study of needs, use and adoption with full-adopters of technology. Journal of Research and Practice in Information Technology, 35(3), 205-220.

clxxxiii. Yomere, G. O., \& Esosa, B. O. (2011). Introduction to business policy and strategy. Warri: Xcel International Limited.

clxxxiv. Yusuf, M. O. (2005). Information and communication technologies and education: Analyzing the Nigerian national policy for information technology. International Education Journal, 6(3), 316-321.

clxxxv. Yusuf, M. O. (2006). Problems and prospects of open and distance education in Nigeria. Turkish Online Journal of Distance Education, 7(1), 22-29.

clxxxvi. Zubairu, S.A. (2013). Assessment of Availability and Utilisation of Information and Communication Technology Resources Among Federal Colleges of Education Lecturers in Content Delivery in Nigeria [An unpublished Dissertation]; Submitted to the Department of Educational Foundations and Curriculum in Partial Fulfilment of the Requirements for the Award of Doctor of Philosophy in Instructional Technology. PP 30, 31, 32, 33, 46, 50, 51, 52

clxxxvii. Zuppo, C.M. (2016). "Defining ICT in a Boundaryless World: The Development of a Working Hierarchy" (PDF). International Journal of Managing Information Technology (IJMT). p. 19. Retrieved 2016-02-13. 